\title{
Distribution characteristics of perfluorinated compounds in major river water and sediment
}

\author{
Min-Kyung Yeo, Eun Hye Hwang and Gi Ho Jeong ${ }^{\star}$ \\ Department of Chemistry, Pusan National University, Busan 609-735, Korea \\ (Received July 26, 2012; Revised September 19, 2012; Accepted September 21, 2012)

\section{우리나라 주요 하천수 및 퇴적토에 축적된 과불화화합물의 분포특성} \\ 여민경 · 황은혜 · 정기호` \\ 부산대학교 화학과 \\ (2012. 6. 26. 접수, 2012. 9. 19. 수정, 2012. 9. 21. 승인)
}

\begin{abstract}
We have developed analysis method of PFCs in river water and sediment, and determined seven species of PFCs such as PFBS, PFHxS, PFOS, PFHpA, PFOA, PFNA and PFDA. Water and sediment samples were collected from 21 and 13 different sites along the Nakdong, Seomjin and Nam River, respectively. The water samples were pretreated with HLB cartridge and sediment samples were concentrated after extracted by sonication, and the levels of PFCs were determined by LC-MS/MS. The coefficient of determination $\left(\mathrm{R}^{2}\right)$ values of calibration curves were higher than 0.99 . The method detection limits ranged $0.09 \sim 0.63 \mathrm{ng} / \mathrm{L}$ in water and $0.013 \sim 0.020 \mathrm{ng} / \mathrm{g}$ in sediment. The recovery rates of PFCs was found to be $74 \sim 98 \%$ for water and $87 \sim 111 \%$ for sediment. PFOA was the major species in water samples and followed by PFHpA and PFOS. In sediment, PFOA, PFOS and PFDA showed similar levels. Both water and sediment samples collected from the Nakdong River showed the highest concentrations of PFCs among the three rivers.

요 약: 본 연구에서는 perfluorobutanesulfonate (PFBS), perfluorohexanesulfonate (PFHxS), perfluorooctanesulfonate (PFOS), perfluoroheptanoate (PFHpA), perfluorooctanoate (PFOA), perfluorononanoate (PFNA) 및 perfluorodecanoate (PFDA) 등 과불화화합물 7 종의 분석방법을 정립하고 우리나라 주요 하천 수 및 퇴적토에 대한 과불화합물의 축적 정도를 분석하고 그 특성을 살펴보았다. 낙동강, 섬진강, 남강을 따라 총 21 개 지점에서 물 시료를, 13 개 지점에서 퇴적토 시료를 채취하였다. 물 시료는 HLB 카트리 지를 이용하여 전처리하였고, 퇴적토 시료는 초음파 추출을 거친 후 농축하였으며 모두 LC-MS/MS로 분 석하였다. 검정곡선의 결정계수 $\left(\mathrm{R}^{2}\right)$ 는 0.99 이상, $\mathrm{MDL}$ 은 물 시료에서 $0.09 \sim 0.63 \mathrm{ng} / \mathrm{L}$, 퇴적토 시료에서 $0.013 \sim 0.020 \mathrm{ng} / \mathrm{g}$ 을 얻었고, 회수율은 물 시료에서 74 98\%, 퇴적토 시료에서 $87 \sim 11 \%$ 로 나타났다. 하천 수에서는 PFOA가 가장 높은 농도를 나타내었고 PFHpA, PFOS가 그 다음으로 높은 농도를 나타냈으며, 퇴적토에서는 PFOA, PFOS 및 PFDA가 비슷한 수준으로 검출되었다. 하천수와 퇴적토 모두 낙동강에서 채취한 시료에서 $\mathrm{PFCs}$ 의 농도가 가장 높게 나타났다.
\end{abstract}

Key words: PFCs, PFOA, PFOS, HLB cartridge, LC-MS/MS

Corresponding author

Phone : +82-(0)51-510-3233 Fax : +82-(0)51-516-7421

E-mail : ghjeong@pusan.ac.kr 


\section{1. 서 론}

과불화화합물(PFCs: perfluorinated compounds)은 탄 소와 불소가 결합된 분자 구조로 그 두 원소 사이의 공유결합이 아주 강하여 분해가 잘 일어나지 않으며, 극한 환경에서도 안정한 화합물이다. 친수성기와 소수 성기를 둘 다 가지는 특별한 성질 때문에 산업적으로 매우 다양하게 사용된다. 특히, 이 물질은 계면활성제 나 물과 기름 등에 의한 오염을 방지하는 표면처리제, 얼룩방지제, 소화제용품 등으로 많이 사용되며, 그 이 외에도 중합체 첨가물, 반도체 세척용제, 살충제, 난연 성 보온재 등 다양한 방면에서 사용된다. ${ }^{1} \mathrm{PFCs}$ 의 특 징은 주로 물로 방출되어 물 표면에 축적되는 것으로 환경 중에 존재하는 $\mathrm{PFCs}$ 는 대부분 물을 따라 이동되 며, 물은 중요한 저장소의 역할을 한다. ${ }^{2}$

$\mathrm{PFCs}$ 는 2009 년 5 월 스톡홀름 협약에서 PFOS가 관리대상물질로 선정되면서 다양한 환경 매체에서의 모니터링이 강화되었다. 이 물질은 탄소와 플루오린으 로 이루어져 있고, 골격은 소수성(hydrophobic)을 지닌 탄소사슬로 구성되어 있고, 끝은 친수성(hydrophilic) 을 지닌 그룹으로 구성되어 있으며, 이 그룹에 따라 크게 perfluorosulfonates (PFSA)와 perfluorocarboxylates (PFCA)로 나뉜다. 이런 특징적인 구조로 인해 소수성 과 친유성(lipophilic)을 갖는 기존의 잔류성 유기오염 물질(POPs, persistent organic pollutants)와는 달리 친 수성과 소유성(lipophobic)을 모두 가지고 있다.

$\mathrm{PFCs}$ 는 난분해성으로 동물이나 인체에 축적되어서 영향을 미치지만 ${ }^{3}$ 다른 POPs들과 달리 수용성이기 때 문에 지방질에는 축적이 잘 되지 않고 단백질과 결합 하여 간에 잘 축적된다고 보고되고 있다.,5 동물을 $\mathrm{PFCs}$ 에 노출시켜 실험한 결과를 보면 간이 비대해지 며 중량이 증가하고, 간질환과 관련된 효소들이 유의 성 있게 증가한다는 결과를 보이며 인체에 매우 유해 하다는 것을 알 수 있다. ${ }^{6}$

PFCs는 전 세계적으로 수질뿐만 아니라 대기, 토양 등 다양한 환경매체에서 발견되며 인간과 동물에게 유해한 영향을 끼칠 수 있다. 이 다양한 환경매체를 통한 장거리 이동으로 오염원과는 거리가 멀리 떨어 진 북극 지방과 북극곰에서도 발견되고 있다. ${ }^{8}$ 특히, $\mathrm{PFOS}$ 와 $\mathrm{PFOA}$ 는 상대적으로 높은 농도로 검출되고 있는데, ${ }^{9}$ 이것은 하수처리장을 거치면서 이 두 물질의 농도가 현저하게 증가하고, ${ }^{10}$ 산업현장에서 많이 사용 되어지지만 완전히 제거되지 못한 채 방류되며, ${ }^{11}$ 다 양한 $\mathrm{PFCs}$ 의 전구물질들의 최종 분해산물이 이 두 물

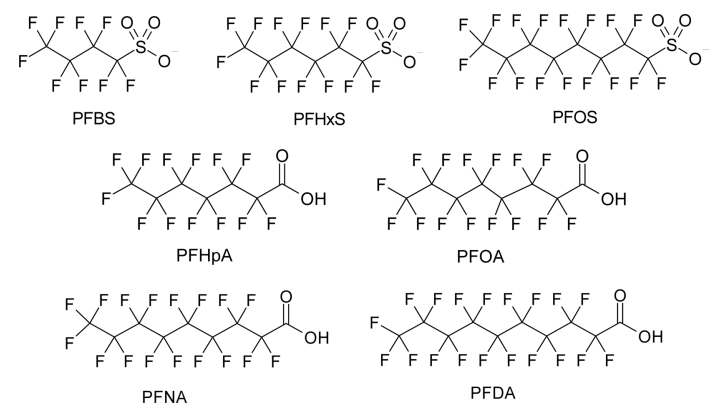

Fig. 1. Chemical structures of PFCs.

질이기 때문이다. ${ }^{12}$

$\mathrm{PFCs}$ 는 광범위하게 사용되며, 미국과 유럽연합에서 발표한 내용에 따르면 소화용 발포제, 카펫, 섬유산업, 코팅제, 살충제 등으로 사용되며, 영국에서 발표한 내 용에 의하면 사진산업, 반도체 산업, 윤활유, 금속 공 정에도 사용된다고 한다. ${ }^{13}$ 직접적인 배출은 제조공정 중 PFCs를 사용하여 배출되는 반면, 간접 배출은 화 학반응 중 비의도적인 불순물이나 전구물질의 분해로 인한 부산물 때문으로 추정된다.

$\mathrm{PFCs}$ 는 전 세계적으로 1951 년부터 2004 년까지 총 4,400 8,000 톤을 생산해 냈다고 보고되고 있다. 이 중에서 직접적인 배출원이 되는 제조공장에서는 1951년부터 2004 년까지 총 470 900 톤을 배출하였 으며, 산업과 소비제품 생산에서는 1951년부터 2000 년까지 총 3,200 6,900 톤을 배출하였다고 보고되었 다. ${ }^{14}$ 이에 비해 간접적인 배출은 1960 년부터 2004 년까지 30 350 톤을 배출한 것으로 총 배출량의 $10 \%$ 정도로 적은 부분을 차지하는 것을 알 수 있다.

본 연구의 목적은 $\mathrm{PFCs}$ 중에서 가장 연구가 활발히 되고 있는 PFOS (perfluoro-1-octanesulfonate)와 PFOA (perfluoro-n-octanoic acid)를 포함하여 PFSA 중 PFBS (perfluoro-1-buanesulfonate), PFHxS (perfluoro-1-hexanesulfonate)와 PFCA 중 PFHpA (perfluoro-n-heptanoic acid), PFNA (perfluoro-n-nonanoic acid), PFDA (perfluoro-n-decanoic acid) 등 총 7 종을 분석대상 물질로 선정하여 주요 하천수와 퇴적토에 축적된 농도를 측 정하고 그 분포특성을 알아보는 데 있다. Fig. 1은 이 들에 대한 분자구조를 나타낸 것이다.

\section{2. 실험 방법 및 재료}

\section{1. 시료채취}

남강, 낙동강, 섬진강의 상류 및 하류 지점을 골고 


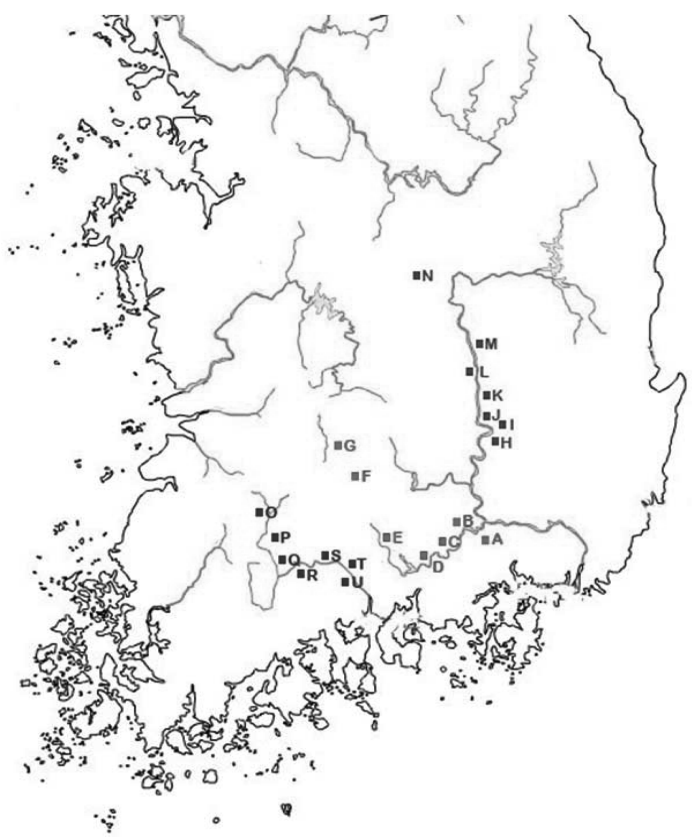

Fig. 2. Locations of sampling sites.

Table 1. Descriptions of sampling site

\begin{tabular}{cll}
\hline \hline & Site & \multicolumn{1}{c}{ Description } \\
\hline & A & Gyungnam Haman Beopsoo \\
& (Outdoor fishing place) \\
Nam & C & Gyungnam Haman Goonbuk \\
River & D & Gyungnam Euiryung Hwajeong \\
& E & Gyungnam Sancheong Danseong \\
& F & Gyungnam Sancheong Saengcho \\
& G & Gyungnam Hamyang Seosang \\
\hline & H & Daegu Dalseong Hwawon \\
& I & Daegu Dalseong Paho \\
Nakdong & J & Daegu Dalseong Dasa \\
River & K & Daegu Dalseong Habin \\
& L & Gyungbuk Chilgok Seokjeok \\
& M & Gyungbuk Gumi Goa \\
& N & Kyungbuk Sangjoo Ian \\
\hline River & O & Jeonbuk Soonchang Jeokseong \\
& P & Jeonbuk Namwon Geumji \\
& Q & Jeonnam Gokseong Jangseon \\
& T & Jeonnam Gokseong Godal \\
& U & Gyungnam Hadong Hwagae Tab Hadong Hwagae Deokeun \\
\hline & &
\end{tabular}

루 포함하여 각 강에서 7 개 지점, 총 21 개 지점을 선택하여 2010 년 8 월 18 일부터 24 일 사이에 시료
를 채취하였다. Fig. 2와 Table 1에 시료를 채취한 위 치와 상세한 장소를 나타냈다. 샘플링에 사용한 채수 병은 폴리프로필렌 재질로 된 것을 사용하였으며, 시 료를 채취하기 전 미리 메탄올과 아세톤으로 3 회 세 척하고, 채취 지점에 가서 해당 시료로 3 회 반복해서 씻어낸 후 시료를 채취하였다. 채취한 시료는 실험실 에 도착하여 즉시 Glass Microfiber Filter(Whatman, $47 \mathrm{~mm}$, Circle, Cat. no. 1825-047)를 사용하여 여과 과정을 거쳤으며 전처리 전까지 $4{ }^{\circ} \mathrm{C}$ 에 냉장 보관하 였다. 시료 채취 후 3 일 내에 필터 처리하였으며, 필 터 후 30 일 내에 분석하였다.

퇴적토 시료는 grab sampler를 이용하여 채취하였 다. 실험실에서 토양 시료를 고르게 펴서 일주일 이 상 자연건조 시킨 후, $100 \mu \mathrm{m}$ 표준체에 통과시켜 폴리에틸렌(PE) 병에 밀폐시켜 분석 전까지 $-20{ }^{\circ} \mathrm{C}$ 에 냉동보관하였다.

\section{2. 시약}

PFBS, PFHxS, PFOS, PFHpA, PFOA, PFNA 및 $\mathrm{PFDA}$ 등 과불화화합물 7 종이 모두 포함된 $\mathrm{MXA}(5$ $\mu \mathrm{g} / \mathrm{mL}, \mathrm{MeOH})$ 와 내부표준물질인 ${ }^{13} \mathrm{C}-\mathrm{PFOA},{ }^{13} \mathrm{C}$ PFOS (각각 $50 \mu \mathrm{g} / \mathrm{mL}, \mathrm{MeOH}$ ) Wellington Lab (Guelph, Ontario, Canada) 제품을 사용하였다. 메탄올과 물은 J.T. Baker (NJ, USA)의 HPLC 등급을 사용하였고, ammonium acetate는 Sigma Aldrich의 HPLC Reagent 용 (Ammonium acetate for HPLC Reagent)을 사용하였다.

\section{3. 기기 및 장치}

정제과정에 사용된 고체상 추출 카트리지는 Waters (Milford, Massachusetts, USA)에서 구입한 Oasis HLB (200 mg, $6 \mathrm{cc}$ )를 사용하였고, manifold와 large volume sampler는 Supelco (Bellefonte, PA, USA)에서 구입하였다.

LC-MS/MS는 Agilent (Palo Alto, CA, USA)의 Agilent 1200 Series HPLC와 Agilents 6410 Triple-quadrupole 을 사용하였다. HPLC에는 Auto Sampler가 장착되어 있었으며 HPLC 컬럼은 Agilent ZORBAX Eclipse $\mathrm{XDB} \mathrm{C}_{18}(4.6 \times 50 \mathrm{~mm}, 1.8 \mu \mathrm{m})$ 을 사용하였다.

$\mathrm{HPLC}$ 의 이동상은 $2 \mathrm{mM}$ ammonium acetate/메탄올 과 $2 \mathrm{mM}$ ammonium acetate/물을 사용하였으며, 이동 상의 유속은 $0.5 \mathrm{~mL} / \mathrm{min}$ 이고 주입량은 $10 \mu \mathrm{L}$ 이었다. 검출에서 전자 분무이온화 방식(electro spray ionization, $\mathrm{ESI})$ 을 사용하였고, negative mode로 측정하였다. 분석 시 선택성 향상을 위해서 MRM(multiple reaction 
Table 2. Optimized conditions for LC-MS/MS

\begin{tabular}{|c|c|c|}
\hline $\mathrm{LC}$ & \multicolumn{2}{|c|}{ Agilent 1200 Series Binary Pump SL } \\
\hline Column & \multicolumn{2}{|c|}{$\begin{array}{l}\text { Agilent ZORBAX Eclipse XDB C18 } \\
\qquad(4.6 \times 50 \mathrm{~mm}, 0.18 \mu \mathrm{m})\end{array}$} \\
\hline Injection volume & \multicolumn{2}{|c|}{$10 \mu \mathrm{L}$} \\
\hline Mobile phase & \multicolumn{2}{|c|}{$\begin{array}{l}\mathrm{A}=2 \mathrm{mM} \text { ammonium acetate in methanol } \\
\mathrm{B}=2 \mathrm{mM} \text { ammonium acetate in water }\end{array}$} \\
\hline Flow rate & \multicolumn{2}{|c|}{$0.5 \mathrm{~mL} / \mathrm{min}$} \\
\hline \multirow{7}{*}{ Gradient } & Time (min) & $\% \mathrm{~B}$ \\
\hline & 0 & 94 \\
\hline & 0.5 & 94 \\
\hline & 8 & 5 \\
\hline & 10.5 & 5 \\
\hline & 11 & 94 \\
\hline & 20 & 94 \\
\hline Total run time & \multicolumn{2}{|c|}{$\begin{array}{l}20 \text { min (including } 9 \text { min } \\
\text { equilibration time) }\end{array}$} \\
\hline MS/MS & \multicolumn{2}{|c|}{ Agilent 6460 Triple Quad LC/MS } \\
\hline Ion Source & \multicolumn{2}{|c|}{ Electrospray negative + Jet Stream } \\
\hline Spray gas & \multicolumn{2}{|c|}{$\mathrm{N}_{2}(40 \mathrm{psi})$} \\
\hline Gas flow & \multicolumn{2}{|l|}{$10 \mathrm{~L} / \mathrm{min}$} \\
\hline Gas temp. & \multicolumn{2}{|l|}{$250{ }^{\circ} \mathrm{C}$} \\
\hline Detection mode & \multicolumn{2}{|c|}{ Multiple Reaction Monitoring (MRM) } \\
\hline
\end{tabular}

monitoring) mode를 사용하였으며, 이 때 충돌 에너지 값은 실험을 통하여 최적값을 찾아 사용하였다. LC$\mathrm{MS} / \mathrm{MS}$ 에 대한 최적 조건과 질량검출 조건은 Table 2 와 3 에 각각 나타내었다.

\section{4. 분석 방법}

\subsection{1. 하천수}

하천수에서의 과불화화합물은 기본적으로 U.S. EPA Method 537을 참고해서 일부 수정하여 분석하였 으며 간단히 요약하면 다음과 같다. 강에서 직접 채취 한 하천수 시료 $500 \mathrm{~mL}$ 를 필터로 부유물질을 걸러낸
후 내부표준물질(MPFOS, MFPOA)을 첨가하였다. $\mathrm{HLB}(200 \mathrm{mg}, 6 \mathrm{cc})$ 카트리지를 사용하기 전 $\mathrm{MeOH}$ $7 \mathrm{~mL}$ 와 증류수 $15 \mathrm{~mL}$ 로 컨디셔닝 한 후, 대용량 시 료공급기를 이용하여 하천수 시료를 용리시켜 준 다 음 증류수 $5 \mathrm{~mL}$ 로 $\mathrm{HLB}$ 를 세척하고, $\mathrm{MeOH} 13 \mathrm{~mL}$ 를 이용하여 $\mathrm{PP}$ 시험관 $(15 \mathrm{~mL})$ 에 용출하였다. 질소를 이용하여 $1 \mathrm{~mL}$ 까지 농축시키고 나일론 필터 $(0.2 \mu \mathrm{m}$, $25 \mathrm{~mm}$ )를 거친 후 $\mathrm{PP}($ polypropylene) 바이알에 옮겨 $\mathrm{LC}-\mathrm{MS} / \mathrm{MS}$ 로 분석하였다.

\subsection{2. 퇴적토}

퇴적토에서의 분석 방법은 Strynar 등이 수행한 방 법을 참고하고 ${ }^{15}$ 일부 수정하여 시행하였으며, 간단히 요약하면 다음과 같다. 퇴적토 시료 $10 \mathrm{~g}$ 에 메탄올 10 $\mathrm{mL}$ 와 내부표준물질(MPFOS, MPFOA)을 첨가하고 진 탕기를 이용하여 $300 \mathrm{rpm}$ 으로 10 분 동안 섞어준다. 이어서 30 분 동안 초음파 추출을 수행한 후 원심분 리기에 넣고 $2500 \mathrm{rpm}$ 으로 15 분 동안 원심분리한 후 에 퇴적토와 완전하게 분리된 상등액을 따라낸다. 남아 있는 퇴적토에 다시 메탄올 $10 \mathrm{~mL}$ 를 첨가하고 한 번 더 반복한 후 질소를 이용하여 $1 \mathrm{~mL}$ 까지 농축시킨다. 농축된 메탄올은 나일론 필터 $(0.2 \mu \mathrm{m}, 25 \mathrm{~mm})$ 를 거친 후 PP 바이알에 옮겨 LC-MS/MS로 분석하였다.

\section{3. 결과 및 고찰}

\section{1. 검정 곡선}

총 10 종의 $\mathrm{PFCs}$ 가 섞인 $5 \mu \mathrm{g} / \mathrm{mL}$ 표준물을 $\mathrm{MeOH}$ 에 희석시켜 $1 \mathrm{ppm}, 50 \mathrm{ppb}, 5 \mathrm{ppb}$ 의 저장 용액을 조제 하였다. 이 저장 용액으로 표준용액이 $0.1,0.2,0.5,2$, $5,10,20,50 \mathrm{ng} / \mathrm{mL}$ 의 농도가 되도록 하고, 내부표준물 질은 각각 $4 \mathrm{ng} / \mathrm{mL}$ 의 농도가 되도록 하였다. 모든 검 정 곡선의 결정계수 $\left(\mathrm{r}^{2}\right)$ 값은 0.99 이상을 보여주었으며 Fig. 3에 PFOS와 PFOA의 검정곡선을 나타내었다.

Table 3. Mass detection conditions of LC-MS/MS

\begin{tabular}{ccccccc}
\hline \hline Compounds & Precursor ion $(\mathrm{m} / \mathrm{z})$ & \multicolumn{2}{c}{ Product ion $(\mathrm{m} / \mathrm{z})$} & \multicolumn{2}{c}{ Collision Energy $(\mathrm{eV})$} & Retention time $(\mathrm{min})$ \\
\hline PFHpA & 363 & 319 & 169 & 2 & 14 & 9.11 \\
PFOA & 413 & 369 & 169 & 2 & 9 & 9.48 \\
PFNA & 463 & 419 & 219 & 4 & 11 & 9.78 \\
PFDA & 513 & 469 & 219 & 4 & 15 & 10.03 \\
PFBS & 299 & 80 & 99 & 30 & 27 & 8.08 \\
PFHxS & 399 & 80 & 99 & 34 & 34 & 9.12 \\
PFOS & 499 & 80 & 99 & 53 & 50 & 9.76 \\
\hline
\end{tabular}


PFOS

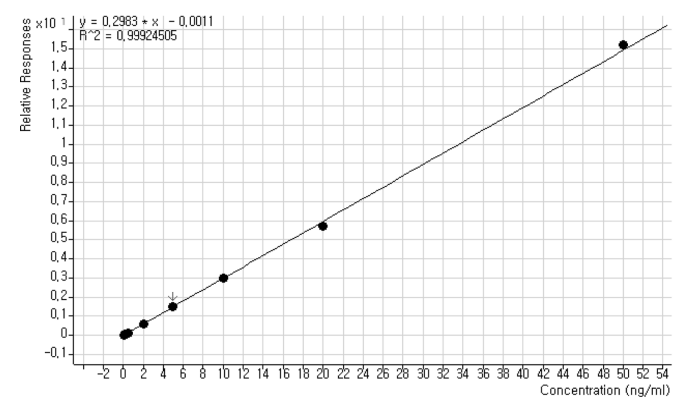

Fig. 3. Calibration curves of PFOS and PFOA.

\section{2. 회수율과 재현성}

회수율 측정은 바탕시료에 일정 농도의 표준물질을 넣고 전처리를 거친 것과 전처리를 거치지 않은 표준
PFOA

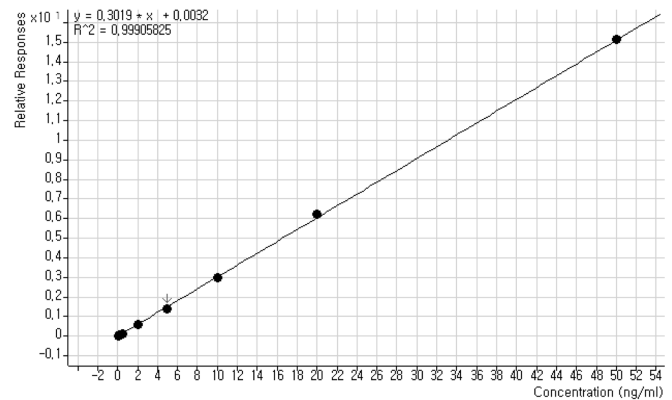

물질의 피크 면적을 비교하여 구하였다. 물과 퇴적토 시료의 회수율은 각각 74 99\%, 87 117\%의 범위를 보였으며, 상대표준편차(RSD)는 각각 4 22\%, 4 6\%

Table 4. Concentration of PFCs in water from the Nam, Nakdong, and Seomjin Rivers (ng/L)

\begin{tabular}{|c|c|c|c|c|c|c|c|c|c|}
\hline River & Site & PFBS & PFHxS & PFOS & PFHpA & PFOA & PFNA & PFDA & $\Sigma$ PFCs \\
\hline \multicolumn{2}{|c|}{ (MDL) } & 0.30 & 0.27 & 0.093 & 0.43 & 0.63 & 0.64 & 0.53 & \\
\hline \multicolumn{2}{|c|}{ Average recovery $(\%)$} & 99 & 82 & 84 & 74 & 83 & 90 & 87 & \\
\hline \multirow{7}{*}{$\begin{array}{l}\text { Nam } \\
\text { River }\end{array}$} & A & 0.72 & 0.43 & 0.98 & 1.9 & 11 & 0.66 & - & 15 \\
\hline & B & 0.32 & - & 0.29 & 0.55 & 2.00 & - & - & 3.2 \\
\hline & $\mathrm{C}$ & - & - & 0.33 & 0.51 & 3.24 & - & - & 4.1 \\
\hline & $\mathrm{D}$ & - & - & 0.23 & 2.05 & 8.26 & - & - & 11 \\
\hline & $\mathrm{E}$ & - & - & 0.42 & - & 0.72 & - & - & 1.1 \\
\hline & $\mathrm{F}$ & - & - & - & - & - & - & - & - \\
\hline & G & - & - & 0.19 & - & 0.74 & - & - & 0.93 \\
\hline \multirow{7}{*}{$\begin{array}{c}\text { Nakdong } \\
\text { River }\end{array}$} & $\mathrm{H}$ & 2.2 & 4.2 & 5.5 & 17 & 67 & 9.7 & 3.3 & 110 \\
\hline & I & 2.0 & 5.2 & 4.1 & 12 & 39 & 39 & 2.0 & 71 \\
\hline & $\mathrm{J}$ & 0.72 & 0.75 & 1.2 & 1.2 & 5.3 & - & - & 9.1 \\
\hline & $\mathrm{K}$ & 1.8 & 6.3 & 6.9 & 7.5 & 39 & 2.0 & - & 63 \\
\hline & $\mathrm{L}$ & 1.0 & 1.4 & 1.4 & 2.4 & 8.6 & 2.0 & 0.88 & 18 \\
\hline & M & 0.33 & 0.54 & 0.22 & - & 1.2 & - & - & 2.3 \\
\hline & $\mathrm{N}$ & - & 0.28 & 0.18 & - & - & - & - & 0.46 \\
\hline \multirow{7}{*}{$\begin{array}{c}\text { Seomjin } \\
\text { River }\end{array}$} & $\mathrm{O}$ & - & - & 0.22 & - & 0.65 & - & - & 0.87 \\
\hline & $\mathrm{P}$ & - & 0.31 & 0.14 & - & 1.6 & - & - & 2.0 \\
\hline & Q & - & 0.32 & 0.17 & - & 0.92 & - & - & 1.4 \\
\hline & $\mathrm{R}$ & - & - & 0.25 & - & 1.3 & - & - & 1.5 \\
\hline & $\mathrm{S}$ & 0.31 & - & 0.14 & - & 0.72 & - & - & 1.2 \\
\hline & $\mathrm{T}$ & - & - & - & - & - & - & - & - \\
\hline & $\mathrm{U}$ & - & - & 0.12 & - & - & - & - & 0.12 \\
\hline \multicolumn{2}{|c|}{ Sum } & 9.3 & 20 & 22 & 46 & 191 & 21 & 6.2 & 315 \\
\hline \multicolumn{2}{|c|}{ Min } & - & - & - & - & - & - & - & - \\
\hline \multicolumn{2}{|c|}{ Max } & 2.2 & 6.3 & 6.9 & 17 & 67 & 9.7 & 3.3 & 110 \\
\hline \multicolumn{2}{|c|}{ Mean } & 0.44 & 0.94 & 1.1 & 2.2 & 9.1 & 0.99 & 0.29 & 15 \\
\hline \multicolumn{2}{|c|}{ Median } & - & - & 0.23 & - & 1.3 & - & - & 2.0 \\
\hline
\end{tabular}

-: below the detection limit

Vol. 25, No. 5, 2012 
Table 5. Concentrations of PFCs in sediment from the Nam, Nakdong, and Seomjin Rivers (ng/g)

\begin{tabular}{|c|c|c|c|c|c|c|c|c|c|}
\hline River & Site & PFBS & PFHxS & PFOS & PFHpA & PFOA & PFNA & PFDA & PFCs \\
\hline \multicolumn{2}{|c|}{ (MDL) } & 0.016 & 0.013 & 0.013 & 0.014 & 0.014 & 0.016 & 0.020 & \\
\hline \multicolumn{2}{|c|}{ Average recovery $(\%)$} & 97 & 89 & 87 & 96 & 112 & 107 & 117 & \\
\hline \multirow{7}{*}{$\begin{array}{l}\text { Nam } \\
\text { River }\end{array}$} & A & - & - & 0.033 & - & 0.024 & 0.038 & 0.024 & 0.12 \\
\hline & B & - & - & 0.20 & 0.037 & 0.20 & 0.12 & 0.20 & 0.75 \\
\hline & $\mathrm{C}$ & & & & & & & & \\
\hline & $\mathrm{D}$ & - & - & 0.61 & 0.041 & 0.22 & 0.054 & 0.30 & 1.2 \\
\hline & $\mathrm{E}$ & - & - & - & - & 0.021 & - & - & 0.021 \\
\hline & $\mathrm{F}$ & - & - & 0.15 & 0.022 & 0.12 & 0.075 & 0.23 & 0.60 \\
\hline & G & & & & & & & & \\
\hline \multirow{7}{*}{$\begin{array}{c}\text { Nakdong } \\
\text { River }\end{array}$} & $\mathrm{H}$ & - & 0.024 & 1.2 & 0.32 & 2.1 & 1.2 & 1.7 & 6.5 \\
\hline & I & & & & & & & & \\
\hline & $\mathrm{J}$ & - & - & 0.31 & - & 0.050 & 0.029 & 0.081 & 0.47 \\
\hline & $\mathrm{K}$ & - & - & 0.26 & 0.053 & 0.15 & 0.055 & 0.15 & 0.66 \\
\hline & $\mathrm{L}$ & - & 0.016 & 0.41 & 0.026 & 0.087 & 0.081 & 0.36 & 0.97 \\
\hline & M & - & - & 0.37 & 0.015 & 0.076 & 0.083 & 0.12 & 0.66 \\
\hline & $\mathrm{N}$ & & & & & & & & \\
\hline \multirow{7}{*}{$\begin{array}{c}\text { Seomjin } \\
\text { River }\end{array}$} & $\mathrm{O}$ & - & - & 0.060 & - & 0.018 & 0.018 & 0.060 & 0.16 \\
\hline & $\mathrm{P}$ & & & & & & & & \\
\hline & Q & - & 0.013 & 0.044 & - & 0.026 & 0.027 & 0.034 & 0.14 \\
\hline & $\mathrm{R}$ & & & & & & & & \\
\hline & $\mathrm{S}$ & - & - & 0.048 & - & 0.015 & - & 0.023 & 0.087 \\
\hline & $\mathrm{T}$ & & & & & & & & \\
\hline & $\mathrm{U}$ & & & & & & & & \\
\hline \multicolumn{2}{|c|}{ Sum } & - & 0.053 & 3.5 & 0.51 & 3.1 & 1.8 & 3.3 & 12 \\
\hline \multicolumn{2}{|c|}{ Min } & - & - & - & - & 0.015 & - & - & 0.021 \\
\hline \multicolumn{2}{|c|}{ Max } & - & 0.024 & 1.2 & 0.32 & 2.1 & 1.2 & 1.2 & 0.021 \\
\hline \multicolumn{2}{|c|}{ Mean } & - & 0.0041 & 0.28 & 0.040 & 0.24 & 0.13 & 0.25 & 0.95 \\
\hline \multicolumn{2}{|c|}{ Median } & - & - & 0.20 & 0.015 & 0.076 & 0.054 & 0.12 & 0.60 \\
\hline
\end{tabular}

-: below the detection limit. : sample was not collected

의 범위를 보였다(Table 4, 5). 데이터 결과를 통계처 리할 때 회수율에 대한 보정은 하지 않았다.

\section{3. 검출한계( $\mathrm{MDL}$, method detection limit)}

표준용액 $0.50 \mathrm{ng} / \mathrm{mL}$ 을 첨가시킨 8 개의 바탕시료 의 표준편차를 구한 후 $2.998(\mathrm{p}=0.99)$ 을 곱하여 $\mathrm{MDL}$ 을 구하였다. 하천수와 퇴적토에서 구한 $\mathrm{MDL}$ 값은 Table 4와 5에 각각 나타내었다.

\section{4. 바탕오염측정}

내부표준물질을 첨가하고 실제 시료와 동일한 방법 으로 전처리 과정을 거쳐 $\mathrm{PFCs}$ 농도를 측정한 결과 검출한계 이하의 값을 나타냈다. 따라서 실험 과정의 추출 단계부터 분석기기 사용까지 바탕오염이 없음을
확인하였다.

\section{5. 하천수에 축적된 PFCs의 농도}

남강, 낙동강, 섬진강 21 개 지점에서 채취한 하천 수에 포함된 PFCs 7 종의 각 지점별 농도는 Table 4 에 정리하여 나타내었다. 하천수 채취 지점은 각 수계 를 따라 상류로부터 하류까지 골고루 분포되어 있다. 본 연구에서 나타낸 총 농도 및 평균값 등 계산으로 구한 값들은 $\mathrm{MDL}$ 보다 낮은 측정값을 0 으로 설정하 고 계산한 값이다.

$\mathrm{PFCs}$ 의 농도 범위는 설폰산류의 $\mathrm{PFBS}$ 는 $<0.30$ (=MDL) $2.2 \mathrm{ng} / \mathrm{L}, \mathrm{PFHxS}$ 는 <0.27 6.3 ng/L 그리고 PFOS는 $<0.093 \sim 6.9 \mathrm{ng} / \mathrm{L}$ 을 나타내었다. 카복실산류의 PFHpA는 $<0.43 \sim 17 \mathrm{ng} / \mathrm{L}, \mathrm{PFOA}$ 는 $<0.63 \sim 67 \mathrm{ng} / \mathrm{L}$, 
PFNA는 $<0.64 \sim 9.7 \mathrm{ng} / \mathrm{L}$, 그리고 PFDA는 $<0.53 \sim 3.3$ $\mathrm{ng} / \mathrm{L}$ 을 나타냈다. Table 4에 나타낸 지점별 각 $\mathrm{PFCs}$ 화학종에 대한 평균 농도와 중앙값을 비교해보면 (mean/median) PFOS는 4.8, PFOA는 7.0, 그리고 나머 지 5 종의 $\mathrm{PFCs}$ 에 대한 중앙값은 모두 검출한계 미만 으로 나타났기 때문에 계산할 수 없음을 알 수 있다. 이것은 다른 지점들에 비해 월등하게 높게 검출된 몇 몇 지점에서의 농도값에 의해 평균 농도가 높게 산출 된 것임을 보여주는 것이며, 전반적으로 하천수에서의 $\mathrm{PFCs}$ 농도는 낮은 수준으로 검출되고 있음을 알 수 있다.

전체 21 개 지점에서 검출된 $\mathrm{PFCs}$ 화학종별 총 농 도를 보면 PFOA가 $191 \mathrm{ng} / \mathrm{L}$ 으로서 전체의 $60 \%$ 를 조 금 초과하여 가장 높게 분포되어 있음을 알 수 있다. 다음으로 PFHpA $46 \mathrm{ng} / \mathrm{L}(15 \%)$, PFOS $22 \mathrm{ng} / \mathrm{L}$ (7.0\%), PFNA $21 \mathrm{ng} / \mathrm{L}$ (6.7\%), PFHxS $20 \mathrm{ng} / \mathrm{L}$ (6.3\%), PFBS $9.3 \mathrm{ng} / \mathrm{L}(2.9 \%)$, 마지막으로 PFDA $6.2 \mathrm{ng} /$ $\mathrm{L}(2.0 \%)$ 로 나타났다. $\mathrm{SPFCs}$ 가 낮아 PFOA가 검출되 지 않은 4 개 지점을 제외하면 PFOA가 나머지 모든 지점에서 가장 우세하게 분포된 화학종임을 알 수 있 다. PFOS 또한 전 지점에 걸쳐 널리 분포되어 있다. $\mathrm{PFCs}$ 항목별 검출빈도를 보면 PFOS가 총농도는 전체 의 $7.3 \%$ 를 차지하여 세 번째로 높게 나타났지만 검출 빈도는 19/21(90\%)로서 가장 널리 분포되어 있는 것 으로 나타났다. PFOS의 검출빈도가 가장 높게 나타난 것은 이 화학종의 검출한계가 $0.093 \mathrm{ng} / \mathrm{L}$ 으로 다른 6 종의 PFCs보다 훨씬 낮기 때문에 더 많은 지점에서 검출된 것으로 보인다. 다음으로 총 농도가 높은 $\mathrm{PFOA}$ 의 검출빈도가 $17 / 21(81 \%)$ 로 나타났으며 검출 된 17 개 모든 지점에서 다른 6 종의 $\mathrm{PFCs}$ 보다 높은 농도로 검출되었다. $\mathrm{PFOA}$ 는 검출한계값이 $0.63 \mathrm{ng} / \mathrm{L}$ 으로서 PFNA와 더불어 가장 높은 값을 보이지만 비 교적 많은 지점에서 검출한계 이상으로 검출되었다. $\mathrm{PFOA}$ 가 검출되지 않은 4 개 지점은 $\mathrm{SPFCs}$ 가 검출한 계 이하 지점이 2 개이고 나머지는 $0.12 \mathrm{ng} / \mathrm{L}$ 과 0.93 $\mathrm{ng} / \mathrm{L}$ 으로서 매우 낮은 농도를 나타낸 곳이다. 나머지 5 개 항목의 $\mathrm{PFCs}$ 에 대한 검출빈도는 $\mathrm{PFHxS} 10$ / 21(48\%), PFHpA 및 PFBS 9/21(43\%), PFNA 5/21(24\%), 마지막으로 PFDA 3/21(14\%)로 나타났다.

지점별 $\mathrm{SPFCs}$ 는 검출한계 미만으로부터 $110 \mathrm{ng} / \mathrm{L}$ 까지 분포되어 있다. 남강 수계의 산청군 생초면과 섬 진강 수계의 화계면 탑리에서 채취한 하천수에서는 PFCs 7 종 모두 검출한계보다 낮은 농도로 나타났다. 화계면 덕은리에서는 PFOS 한 종만 $0.12 \mathrm{ng} / \mathrm{L}$ 으로
매우 낮게 검출되었다. $\mathrm{PFCs}$ 중 2 종만 검출된 곳이 다섯 지점으로서 $\Sigma \mathrm{PFCs}$ 가 $0.46 \sim 1.5 \mathrm{ng} / \mathrm{L}$ 범위에 분포 되어 있으며 가장 높은 지점도 전체 평균 농도의 $10 \%$ 에 해당되는 낮은 수준을 보이고 있다. 검출된 2 종의 화학종은 상주군 이안면에서 $\mathrm{PFOS}$ 외에 $\mathrm{PFHxS}$ 가 검출된 것을 제외하면 모두 PFOS와 PFOA가 검출 되고 있어 이들 두 화학종이 가장 널리 분포되어 있 음을 보여주고 있다. PFCs 7 종이 모두 검출되었거나 가장 낮은 농도로 분포된 PFDA를 제외한 6 종이 검 출된 지점은 모두 5 개 지점이었으며 이들 지점에서 검출된 $\Sigma \mathrm{PFCs}$ 는 15 110 ng/L 범위에 분포되어 모두 전체 지점의 $\Sigma \mathrm{PFCs}$ 의 평균값보다 높게 나타나고 있 다. 이는 여러 화학종이 검출될수록 $\mathrm{PFCs}$ 가 높아질 수 있음을 보여주는 것이다. 특히 낙동강 수계의 달성 군 화원읍, 파호동 및 하빈면에서 채취한 하천수에서의 $\Sigma \mathrm{PFCs}$ 는 각각 $110,71,63 \mathrm{ng} / \mathrm{L}$ 로서 다른 지점들에 비 해 월등하게 높은 농도로 검출되었으며 총 21 개 지점 에서 구한 $\mathrm{\Sigma PFCs}$ 의 $77 \%$ 를 차지하고 있다. 이들 3 개 지점을 제외한 다른 18 개 지점에 대한 $\mathrm{SPFCs}$ 는 18 $\mathrm{ng} / \mathrm{L}$ 이하의 아주 낮은 농도로 검출되었다.

본 연구에서 조사한 지점 중 $\mathrm{A}$-지점은 하천수가 아 닌 민물고기를 양식하는 낚시터로 만들어진 곳이다. 이 지점에서 $\mathrm{PFDA}$ 를 제외한 6 종의 $\mathrm{PFCs}$ 가 검출되 었고 각각의 농도가 전체 21 개 지점의 평균 농도와 유사한 값을 보이는 것이 흥미롭다. 부근 남강 수계의 $\mathrm{D}$-지점을 제외한 다른 지점과 비교하면 상당히 높은 수준으로 나타났다.

시료 채취 지점 중 각 하천의 가장 상류에 해당되 는 남강 수계의 함양군 서상면, 낙동강 수계의 상주군 이안면, 그리고 섬진강 수계의 순창군 적성면에서 검 출된 $\Sigma \mathrm{PFCs}$ 는 각각 $0.93 \mathrm{ng} / \mathrm{L}, 0.46 \mathrm{ng} / \mathrm{L}$, 그리고 $0.87 \mathrm{ng} / \mathrm{L}$ 로서 모두 $1.0 \mathrm{ng} / \mathrm{L}$ 미만의 낮은 농도로 검 출되었다. 각 지점별 하천수에서 검출된 $\mathrm{SPFCs}$ 를 수 계별로 평균값을 보면 남강 $5.0 \pm 5.8 \mathrm{ng} / \mathrm{L}$, 낙동강 $39 \pm 42 \mathrm{ng} / \mathrm{L}$, 그리고 섬진강 $1.0 \pm 0.7 \mathrm{ng} / \mathrm{L}$ 로 나타났으 며, 섬진강 수계의 지점들이 낮은 농도로 좁은 농도 범위에서 비슷한 수준으로 분포되어 있음을 알 수 있 다. 실제 섬진강 수계 7 개 지점에서의 $\mathrm{PFCs}$ 분포는 검출한계 미만으로부터 $2.0 \mathrm{ng} / \mathrm{L}$ 까지 분포되어 있으 며, 남강 수계의 채취 지점에서는 검출한계 미만부터 $15 \mathrm{ng} / \mathrm{L}$ 까지 분포되어 있고, 다른 수계보다 농도가 높 게 나타난 낙동강 수계의 지점에서는 $0.46 \sim 110 \mathrm{ng} / \mathrm{L}$ 까지 매우 넓은 범위에 걸쳐 분포되어 있음을 알 수 있다. 검출한계 미만으로 처리한 측정값을 0 으로 간주 
하고 구한 전체 21 개 지점에 대한 평균 농도는 $15 \pm 29 \mathrm{ng} / \mathrm{L}$ 로 나타났다. 평균보다 높은 농도로 검출 된 지점은 남강 수계 1 개 지점과 낙동강 수계 4 개 지점이었다. 이들 5 개 지점의 $\Sigma \mathrm{PFCs}$ 의 합은 $274 \mathrm{ng} /$ $\mathrm{L}$ 으로서 전체 농도의 $88 \%$ 를 차지하고 있고, 이 중 $\mathrm{PFOA}$ 가 $164 \mathrm{ng} / \mathrm{L}$ 으로 $59 \%$ 를 약간 초과하여 전체 21 개 지점의 $\Sigma \mathrm{PFCs}$ 에서 차지하는 비율과 거의 비슷한 값을 나타내고 있다.

주요 하천별 $\Sigma \mathrm{PFCs}$ 는 남강 수계에서 $35 \mathrm{ng} / \mathrm{L}$, 낙동 강 수계에서 $270 \mathrm{ng} / \mathrm{L}$, 그리고 섬진강 수계에서 7.1 $\mathrm{ng} / \mathrm{L}$ 으로 나타났다. 낙동강 수계에서 총농도의 $87 \%$ 정도가 검출되어 대부분을 차지하고 있는 것으로 나 타났으며 다음은 남강 수계가 $11 \%$ 를 차지하였고 그 리고 섬진강 수계에서는 $2.2 \%$ 로서 매우 낮은 수준으 로 검출되었다.

\section{6. 퇴적토 축적된 PFCs의 농도}

남강, 낙동강, 섬진강 13 개 지점에서 채취한 퇴적 토에 축적된 PFCs 7 종의 각 지점별 농도를 Table 5 에 정리하여 나타내었다. 하천수를 채취한 21 개 지점 중 8 개 지점의 퇴적토는 거의 모래로만 구성되어 있 어서 분석시료로 사용할 수 없었다. 여기서 나타낸 총 농도 및 평균값 등은 MDL보다 낮은 측정값을 0 으로 설정하고 계산한 값이다.

설폰산류 중 PFBS는 어느 지점에서도 검출되지 않 았고, $\mathrm{PFHxS}$ 는 $<0.031$ (=MDL) $0.024 \mathrm{ng} / \mathrm{g}$ 그리고 PFOS 는 $<0.013(=\mathrm{MDL})-0.28 \mathrm{ng} / \mathrm{g}$ 으로 나타났다. 카복실산류 의 PFHpA는 $<0.014 \sim 0.32 \mathrm{ng} / \mathrm{g}$, PFOA가 $<0.014 \sim 2.1 \mathrm{ng} /$ $\mathrm{g}$, PFNA는 $<0.016 \sim 1.2 \mathrm{ng} / \mathrm{g}$, 그리고 PFDA는 $<0.020$ $1.2 \mathrm{ng} / \mathrm{g}$ 으로 나타났다.

Table 5에 나타낸 $\mathrm{PFCs}$ 의 지점별 각 화학종에 대한 평균 농도와 중앙값의 비(mean/median)를 보면 $\mathrm{PFOS}$ 1.4, PFHpA 2.7, PFOA 3.2, PFNA 2.4, PFDA 2.1이 며 $\mathrm{PFBS}$ 와 $\mathrm{PFHxS}$ 는 중앙값이 검출한계 미만으로 나 타나 계산할 수 없음을 알 수 있다. $\mathrm{PFOS}$ 를 제외한 다른 화학종들은 평균값이 중앙값에 비해 2 배 이상 높았으며, 이는 퇴적토 역시 하천수와 같이 다른 지점 들에 비해 월등하게 높게 검출된 몇몇 지점에 의해 평균값이 높게 산출된 것임을 알 수 있다. 거의 검출 되지 않은 $\mathrm{PFBS}$ 와 $\mathrm{PFHxS}$ 를 제외하고 나머지 화학종 들은 낙동강 수계의 퇴적토에서 가장 높은 농도를 나 타내고 있다. 남강 퇴적토에서도 $\mathrm{PFBS}$ 와 $\mathrm{PFHxS}$ 를 제 외하고는 그래프 상에서 확인할 수 있을 정도의 농도 가 검출되었으나 낙동강 퇴적토보다는 낮은 값이다.
섬진강 퇴적토에서는 PFCs 7 종 모두 아주 낮은 농도 를 나타내고 있다.

지점별 $\Sigma \mathrm{PFCs}$ 는 $0.021 \mathrm{ng} / \mathrm{g}$ 부터 $6.5 \mathrm{ng} / \mathrm{g}$ 까지 분포 되어 있다. PFBS는 어느 지점에서도 검출되지 않았고, 가장 낮은 농도로 분포된 $\mathrm{PFHxS}$ 는 남강 수계의 $\mathrm{H}, \mathrm{L}$ 지점과 섬진강 수계의 $\mathrm{Q}$ 지점에서만 검출되었다. 남 강 수계의 $\mathrm{E}$ 지점에서는 $\mathrm{PFOA}$ 한 화학종만 0.021 $\mathrm{ng} / \mathrm{g}$ 으로 매우 낮게 검출되었고, $\mathrm{PFCs}$ 중 3 종만 검출 된 곳은 섬진강 수계의 $\mathrm{S}$ 지점 하나로 $\mathrm{PPFCs}$ 가 0.087 $\mathrm{ng} / \mathrm{g}$ 이었다. 어느 지점에서도 검출되지 않은 PFBS를 제외한 나머지 6 종의 $\mathrm{PFCs}$ 가 모두 검출된 지역은 낙 동강 수계의 $\mathrm{H}$ 와 L 지점으로 $\Sigma \mathrm{PFCs}$ 는 각각 $6.5 \mathrm{ng} / \mathrm{g}$ 과 $0.97 \mathrm{ng} / \mathrm{g}$ 으로 나타났다. 낙동강 수계의 $\mathrm{H}$ 지점은 총 13 개 지점 중 가장 높은 농도를 나타낸 지점이고, $\mathrm{L}$ 지점은 세 번째로 높은 농도를 나타낸 지점으로서 검출되는 화학종의 수가 많을수록 $\Sigma \mathrm{PFCs}$ 가 높아지는 경향이 있다. 위에서 언급한 4 개 지점을 제외하고 나 머지 9 개 지점에서는 4 5 종의 PFCs가 검출되었다. 전체 13 개 지점 중 2 개 지점을 제외하고 모두 $\mathrm{PFOS}, \mathrm{PFOA}, \mathrm{PFNA}, \mathrm{PFDA}$ 가 검출되어, 퇴적토에는 이 4 종의 PFCs가 널리 분포되어 있는 것으로 나타났 다. 가장 높은 농도를 나타낸 낙동강의 $\mathrm{H}$ 지점에서의 $\mathrm{PFCs}$ 는 $6.5 \mathrm{ng} / \mathrm{g}$ 으로 다른 지점에 비해서 비교적 높 게 검출되었지만 농도 자체는 하천수에 비해 크게 낮 은 편이다. 다음으로 남강 수계의 $\mathrm{D}$ 지점에서 $1.2 \mathrm{ng} / \mathrm{g}$ 이 검출되었다. $\mathrm{H}$ 지점은 상대적으로 매우 높게 나와 총 13 개 지점에서 구한 $\mathrm{\Sigma PFCs}$ 의 $54 \%$ 를 차지하고 있다. 이 지점에 이어 두 번째 높은 농도로 $1.2 \mathrm{ng} / \mathrm{g}$ 이 검출된 $\mathrm{D}$ 지점을 제외하고는 모두 $1.0 \mathrm{ng} / \mathrm{g}$ 보다 낮은 농도로 검출되었다. $\mathrm{H}$ 지점을 제외한 나머지 12 개 지점에서의 $\Sigma \mathrm{PFCs}$ 평균은 $0.49 \pm 0.38 \mathrm{ng} / \mathrm{g}$ 이다. 낙동강 수계에서는 전 지점에서 이 평균보다 높게 검출되었 으며 남강 수계에서는 5 개 지점 중 2 개 지점에서 평균보다 높았고, 섬진강에서는 평균을 넘는 지점이 하나도 없었다. 이와 같이 퇴적토에서의 수계별 $\Sigma \mathrm{PFCs}$ 값의 크기는 하천수에서와 같은 경향을 보이고 있다.

각 지점별 퇴적토에서 검출된 $\Sigma \mathrm{PFCs}$ 의 수계별 평 균을 보면 남강 $0.54 \pm 0.49 \mathrm{ng} / \mathrm{g}$, 낙동강 $1.9 \pm 2.6 \mathrm{ng} / \mathrm{g}$, 그리고 섬진강 $0.13 \pm 0.04 \mathrm{ng} / \mathrm{g}$ 으로 나타났으며, 섬진 강 수계의 지점들이 하천수에서와 마찬가지로 낮은 농도로 좁은 농도 범위에 분포되어 있음을 알 수 있 다. 여기에는 섬진강에서 퇴적토를 채취한 지점수가 다른 수계에 비해 적은 것도 결과에 기여한 것으로 
보인다. 실제 섬진강 수계 세 지점에서의 $\Sigma \mathrm{PFCs}$ 범위 는 $0.087 \sim 0.16 \mathrm{ng} / \mathrm{g}$ 로서 낙동강 수계 다섯 지점에서는 $0.47 \sim 6.5 \mathrm{ng} / \mathrm{g}$ 으로서 섬진강 수계에서 검출된 가장 높 은 농도 값인 $0.16 \mathrm{ng} / \mathrm{g}$ 은 낙동강 수계에서 검출된 가 장 낮은 농도값 $0.47 \mathrm{ng} / \mathrm{g}$ 보다 훨씬 낮게 나타났다.

$\mathrm{PFOA}, \mathrm{PFOS}$ 및 $\mathrm{PFDA}$ 는 전 지점에 걸쳐 널리 분 포되어 있으며 검출빈도는 PFOA $100 \%(13 / 13)$ PFOS 및 PFDA는 92\% (12/13)를 보이고 있다. 반면 PFBS는 어느 지점에서도 검출되지 않았다. $\mathrm{PFOS}$ 와 PFDA가 검출되지 않은 $\mathrm{E}$ 지점은 $\mathrm{PFOA}$ 만 $0.021 \mathrm{ng} / \mathrm{g}$ 의 매우 낮은 농도로 검출되어 다른 화학종의 분포 특성을 볼 수 없었다. PFDA는 검출한계 값이 $0.020 \mathrm{ng} / \mathrm{g}$ 으로 분 석물로 정한 7 종의 $\mathrm{PFCs}$ 중 가장 높은 값을 보이지 만 거의 대부분의 지점에서 검출되었다.

$\mathrm{PFOA}, \mathrm{PFOS}$ 및 PFDA가 $\mathrm{PFCs}$ 에서 차지하는 비 율도 $81 \%$ 로 매우 높게 나타났다. PFNA는 2 개 지점 을 제외한 11 개 지점에서 검출되어 $85 \%(11 / 13)$ 의 높 은 검출빈도를 나타냈으며 총 농도는 전체의 $14 \%$ 를 차지하며 네 번째로 높게 나타났다. 나머지 2 개의 항 목의 PFCs에 대한 검출빈도는 $\mathrm{PFHxS} 23 \%(3 / 13), 9 /$ 21), PFHpA 54\% (7/13)로 나타났다.

하천수와 퇴적토에서 검출된 $\mathrm{PFCs}$ 의 화학종별 총 량과 분포 비율은 Table 6에 정리하여 나타내었다. 전 체 13 개 지점에서 검출된 $\mathrm{PFCs}$ 화학종별 총 농도(비 율)를 보면 $\mathrm{PFOS}, \mathrm{PFOA}$ 및 $\mathrm{PFDA}$ 를 보면 각각 3.5 $\mathrm{ng} / \mathrm{g}(29 \%), 3.1 \mathrm{ng} / \mathrm{g}(25 \%)$ 및 $3.3 \mathrm{ng} / \mathrm{g}(27 \%)$ 로서 세 화학종이 비슷한 농도로 분포되어 있다. 이는 하천수 에서 PFOA가 $60 \%$ 를 차지하여 두 번째로 높은 비율 을 나타낸 PFHpA의 $15 \%$ 보다 압도적으로 높은 비율 을 차지하는 것과는 다른 양상을 나타낸 것이다. 또한 $\mathrm{PFDA}$ 가 $27 \%$ 로서 높은 비율을 차지하는 것도 같은

Table 6. Total amounts and proportions of individual PFC in river water and sediment (summed from the 21 and 13 sampling sites of water and sediment, respectively)

\begin{tabular}{lcccc}
\hline \hline & $\begin{array}{c}\text { Water } \\
(\mathrm{ng} / \mathrm{L})\end{array}$ & $\begin{array}{c}\text { Proportion } \\
(\%)\end{array}$ & $\begin{array}{c}\text { Sediment } \\
(\mathrm{ng} / \mathrm{g})\end{array}$ & $\begin{array}{c}\text { Proportion } \\
(\%)\end{array}$ \\
\hline PFBS & 9.3 & 2.9 & & \\
PFHxS & 20 & 6.3 & 0.053 & 0.43 \\
PFOS & 22 & 7.0 & 3.5 & 29 \\
PFHpA & 46 & 15 & 0.51 & 4.2 \\
PFOA & 191 & 60 & 3.1 & 25 \\
PFNA & 21 & 6.7 & 1.8 & 15 \\
PFDA & 6.2 & 2.0 & 3.3 & 27 \\
\hline Sum & 316 & & 12 & \\
\hline
\end{tabular}

물질이 하천수에서 $2.0 \%$ 를 차지하는 것과 비교하여 퇴적토에서의 특징적인 분포로 보인다. 하천수와 퇴적 토 모두 카복실산류가 각각 $84 \%$ 와 $71 \%$ 를 차지하여 설폰산류보다 훨씬 높은 비율로 검출된 것은 공통적 인 분포특성으로 나타났다.

\section{7. $\mathrm{PFCs}$ 의 탄소사슬의 길이와 농도와의 상관 관계}

Labadie와 Chevreuil의 연구결과에 따르면 PFHxA 에서 PFDoA로, PFBS에서 PFOS로 탄소 사슬이 길어 질수록 $\log K_{\mathrm{oc}}$ 값 역시 증가하는 경향을 보이는 것으 로 알려져 있다. ${ }^{16}$ 본 연구에서도 탄소사슬의 길이가 증가함에 따라 축적되는 농도에 일정한 상관관계가 있는 지 보기 위하여 아래의 관계식을 적용하였다.

$$
K_{\text {oc }}=K_{\mathrm{d}} \times\left(1000 / f_{\mathrm{oc}}\right), K_{\mathrm{d}}=C_{\text {sed }} / C_{\text {water }}
$$

여기서 $K_{\mathrm{oc}}$ 는 퇴적토-하천수 사이의 분배계수이고, $K_{\mathrm{d}}$ 는 퇴적토에서의 $\mathrm{PFC}$ 농도 $\left(C_{\mathrm{sed}}, \mathrm{ng} / \mathrm{kg}\right)$ 를 하천수에서의 $\mathrm{PFC}$ 농도 $\left(C_{\text {water }}, \mathrm{ng} / \mathrm{L}\right)$ 로 나눈 값으로 단위는 $\mathrm{L} \mathrm{kg}^{-1}$ 이 되고, $f_{\mathrm{oc}}$ 는 총 유기탄소 함량을 나타낸 것이다.

본 연구에서 PFBS에서 PFOS까지 분석을 하였지만 검출한계 미만으로 검출된 지점이 많아 $K_{\mathrm{d}}$ 값을 구할 수 없어 결과 비교가 어려웠고, 낙동강 수계의 $\mathrm{H}$ 와 L 지점에서만 PFHpA부터 PFDA까지 모두 검출한계 이 상으로 검출되었으므로 이 두 지점을 대상으로 $\log$ $K_{\mathrm{oc}}$ 값을 계산하였다. 실험에서 구한 $\mathrm{H}$ 및 $\mathrm{L}$ 지점에서 의 $f_{\mathrm{oc}}$ 값은 각각 $4.41 \%$ 및 $3.13 \%$ 이었다. $\mathrm{H}$ 지점에서의 $\log K_{\text {oc }}$ 값은 PFHpA 2.6, PFOA 2.9, PFNA 3.4 그리고 PFDA 4.1을 나타냈으며 $\mathrm{L}$ 지점에서의 $\mathrm{PFHpA}$ 와 $\mathrm{PFOA}$ 는 2.5, PFNA는 3.1, PFDA는 4.1로 나타났다. 본 연구에서 측정된 $\mathrm{PFOA}$ 의 $\log K_{\mathrm{oc}}$ 값은 중국의 $\mathrm{Liao}$ 강 과 Taihu호수에서 측정된 $2.28 \pm 0.42,2.28 \pm 0.55$ 값보다 조금 높게 나타났다. ${ }^{17} \mathrm{H}$ 와 L지점에서 $\log K_{\mathrm{oc}}$ 값과 사 슬길이 사이에는 Fig. 4에 나타낸 바와 같이 결정계수, $\mathrm{R}^{2}$ 값이 각각 0.97 및 0.84 로서 높은 상관관계를 보임으 로써 Labadie와 Chevreuil의 연구결과와 유사한 경향을 보이고 있다. 이는 사슬의 길이가 퇴적토에 흡착되는 경향에 큰 영향을 미치는 것임을 보여주는 것이다.

\section{8. 우리나라 및 외국 사례와의 비교}

우리나라 서해안 지역의 시화호와 아산 등 몇 지점 에서 채취한 물에서 검출된 $\mathrm{PFCs}$ 의 농도 범위는 PFOA 2.95 68.6 ng/L, PFOS 4.11 450 ng/L, PFHpA $<\mathrm{MDL} \sim 47.2 \mathrm{ng} / \mathrm{L}$, PFBS $<\mathrm{MDL} \sim 39.8 \mathrm{ng} / \mathrm{L}$, PFHxS 0.38

Vol. 25, No. 5, 2012 


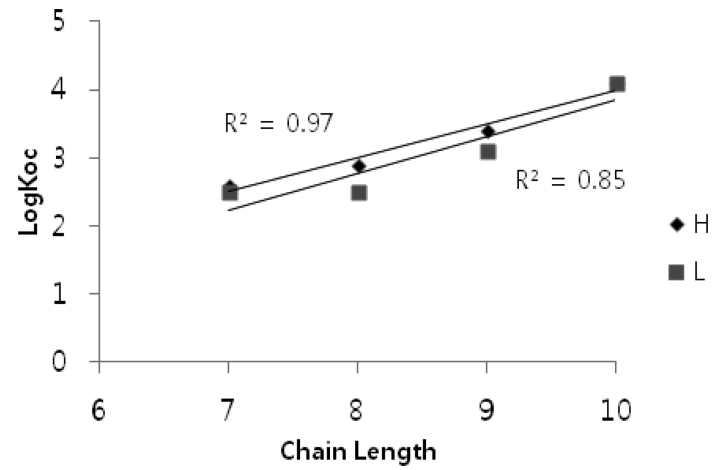

Fig. 4. Correlations of $\log K_{\mathrm{oc}}$ and chain length PFCs.

41.8 ng/L, PFNA 1.38 14.3 ng/L, 그리고 PFDA 0.23 $15.4 \mathrm{ng} / \mathrm{L}$ 등으로 나타났다. ${ }^{18}$ 이 연구에서 구한 PFCs 농도는 시화호 내외부, 아산만 호수 내외부, 금강 및 영산강의 댐 내외부 그리고 몇몇 해변지역 등 15 개 지점에서 구한 것으로서 시료 채취 지점에 따라 큰 변동을 보임을 알 수 있다. PFOA와 PFNA가 본 연구 에서 구한 농도와 비슷한 범위를 보이는 것을 제외하 면 나머지 5 종의 $\mathrm{PFCs}$ 는 최소 2.8 배로부터 최대 65 배까지 훨씬 높은 농도를 보이고 있다.

타이완 북부의 Tour-Chayn강의 하천수에서 검출된 $\mathrm{PFOA}, \mathrm{PFOS}$ 및 $\mathrm{PFDA}$ 의 농도는 각각 $113,4.0$ 및 14 $\mathrm{ng} / \mathrm{L}$ 이었고 같은 지역의 Nan-Kan강의 하천수에서는 이들 화학종이 각각 181,79 및 $21 \mathrm{ng} / \mathrm{L}$ 수준이었다. ${ }^{19}$ Tour-Chayn강의 PFOS는 우리나라 낙동강 수계에서 검출된 농도 중 최고값과 비슷한 수준이고 나머지는 모두 본 연구에서 조사한 하천수에서 검출된 농도 중 최대값보다 최소 1.7 배에서 최대 11 배까지 높은 농 도를 보여주고 있다. 미국 Tennessee강의 여러 지점에 서 검출된 $\mathrm{PFOS}$ 와 $\mathrm{PFOA}$ 의 농도는 각각 $16.8 \sim 144$ $\mathrm{ng} / \mathrm{L}$ 와 <25 598 ng/L 범위로 분포되어 있었으며 $\mathrm{PFCs}$ 를 사용하는 제조공장 부근에서 높은 농도를 보 여주는 특징이 있다. ${ }^{20} \mathrm{PFOA}$ 에 대한 검출한계가 25 $\mathrm{ng} / \mathrm{L}$ 로 본 연구에 비해 매우 높아 이 화학종의 낮은 농 도에 대한 비교는 어렵지만 검출한계 이상으로 나타난 지점에서는 평균 $389 \pm 130 \mathrm{ng} / \mathrm{L}$ 그리고 농도 범위는 $140 \sim 598 \mathrm{ng} / \mathrm{L}$ 로 나타났다. 이는 본 연구에서 측정한 지 점별 평균 $9.1 \pm 17 \mathrm{ng} / \mathrm{L}$, 농도 범위 <0.63(=MDL) 67 $\mathrm{ng} / \mathrm{L}$ 보다 훨씬 높은 농도로 분포되어 있음을 보여주 는 것이다. PFOS의 경우에도 Tennessee강의 각 지점 별 평균은 $69.2 \pm 43.9 \mathrm{ng} / \mathrm{L}$, 농도 범위는 $16.8 \sim 144 \mathrm{ng} /$ $\mathrm{L}$ 로서 본 연구에서 나타난 평균 $1.1 \pm 1.9 \mathrm{ng} / \mathrm{L}$, 농도 범위 $<0.093 \sim 6.9 \mathrm{ng} / \mathrm{L}$ 와 비교하여 월등하게 높은 값
임을 알 수 있다. Tennessee강의 일부 지점에서 관찰 된 아주 높은 농도는 $\mathrm{PFCs}$ 를 사용하는 제조공장 부근 의 하천수를 대상으로 조사한 것이 주요 원인이라고 할 수 있다. 오스트리아의 Danube강과 Schwechat 및 Liesing 두 곳의 지류에서 채취한 하천수에 포함된 $\mathrm{PFCs}$ 의 농도 범위를 보면 $\mathrm{PFOA}$ 와 $\mathrm{PFOS}$ 는 각각 $<1.1 \sim 19 \mathrm{ng} / \mathrm{L}$ 와 $<4.0 \sim 35 \mathrm{ng} / \mathrm{L}$ 이었고, PFNA와 PFDA 는 검출한계 미만으로 나타났으며, $\mathrm{PFHpA}$ 는 최대 3.2 $\mathrm{ng} / \mathrm{L}$ 이었다. ${ }^{21}$ 본 연구에서 구한 하천수에서의 $\mathrm{PFCs}$ 농도와 비교하면 PFOS 농도가 최대 $35 \mathrm{ng} / \mathrm{L}$ 로 높은 것을 제외하면 비교 대상이 되는 나머지 4 종의 PFCs 의 농도는 모두 낮게 나타났다.

\section{4. 결 론}

남강, 낙동강 및 섬진강 수계 각각 7 개 지점 총 21 개 지점에서 채취한 하천수에 포함된 $\mathrm{PFCs} 7$ 종 (PFOA, PFHpA, PFOS, PFNA, PFHxS, PFBS, PFDA) 의 농도 분포는 $\mathrm{PFOA}$ 가 전체의 $60 \%$ 를 조금 초과하 여 가장 높았으며, 다음으로 $\mathrm{PFHpA}(15 \%), \mathrm{PFOS}$ (7.3\%), PFNA(6.6\%), PFHxS (6.3\%), PFBS (3.0\%), 마 지막으로 PFDA $(2.0 \%)$ 의 순서로 나타났다. 수계별로 보면 낙동강 수계에서 총농도의 $87 \%$ 정도가 검출되 어 대부분을 차지하고 있었고, 다음은 남강 수계가 $11 \%$ 를 차지하였고 그리고 섬진강 수계에서는 $2.2 \%$ 로 서 상대적으로 매우 낮은 수준으로 검출되었다. PFCs 의 화학종별로 측정된 농도 범위는 $\mathrm{PFOA}$ 가 $<0.63$ (=MDL) 67 ng/L, PFHpA는 <0.43 17 ng/L, PFOS는 $<0.093 \sim 6.9 \mathrm{ng} / \mathrm{L}, \mathrm{PFNA}$ 는 $<0.64 \sim 9.7 \mathrm{ng} / \mathrm{L}, \mathrm{PFHxS}$ 는 $<0.27 \sim 6.3 \mathrm{ng} / \mathrm{L}, \mathrm{PFBS}$ 는 $<0.30 \sim 2.17 \mathrm{ng} / \mathrm{L}$, 그리고 $\mathrm{PFDA}$ 는 $<0.53 \sim 3.3 \mathrm{ng} / \mathrm{L}$ 을 나타냈다. 퇴적토에서 PFBS 를 제외한 화학종별로 측정된 농도 범위는 $\mathrm{PFHxS}$ 가 $<0.031$ (=MDL) $0.024 \mathrm{ng} / \mathrm{g}$, PFOS는 $<0.013 \sim 0.28 \mathrm{ng} /$ $\mathrm{g}, \mathrm{PFHpA}$ 는 $<0.014 \sim 0.32 \mathrm{ng} / \mathrm{g}, \mathrm{PFOA}$ 는 $<0.014 \sim 2.1$ $\mathrm{ng} / \mathrm{g}, \mathrm{PFNA}$ 는 $<0.016 \sim 1.2 \mathrm{ng} / \mathrm{g}, \mathrm{PFDA}$ 는 $<0.020 \sim 1.2$ $\mathrm{ng} / \mathrm{g}$ 을 나타냈다. 전체적으로 하천수와 퇴적토의 농도 는 다른 나라의 경우와 비교하면 비교적 낮은 수준으 로 축적되어 있는 것으로 보인다. 하천수에서 PFOA 가 $60 \%$ 를 차지하여 두 번째로 높은 비율을 나타낸 $\mathrm{PFHpA}$ 의 $15 \%$ 보다 압도적으로 높은 비율을 차지하지 만 퇴적토에서는 PFOS, PFOA 및 PFDA 세 화학종이 비슷한 농도로 분포되어 있다. 특히 퇴적토에서 PFDA가 매우 높은 비율을 차지하는 것은 이 물질이 하천수에서 $2.0 \%$ 를 차지하는 것과 비교하면 퇴적토에 
서의 특징적인 분포로 보인다. 하천수와 퇴적토 모두 카복실산류가 설폰산류보다 훨씬 높은 비율로 검출된 것은 공통적인 분포특성으로 나타났다.

\section{감사의 글}

이 논문은 부산대학교 자유과제 학술연구비(2년)에 의하여 연구되었으며, 이에 감사드립니다.

\section{참고문헌}

1. K. Prevedouros, I. T. Cousins, R. C. Buck and S. H. Korzeniowski, Environ. Sci. Technol., 40, $32-44$ (2006).

2. M. McLachlan, K. E. Holmstroem, M. Reth and U. Berger, Environ. Sci. Technol., 41(21), 7260-7265 (2007).

3. F. D. Gilliland and J. S. Mandel, American J. Industrial Medicine, 29(5), 560-568(1996).

4. C. Lau, K. Anitole, C. Hodes, D. Lai, A. Pfahles-Hutchens and J. Seed, Toxicol. Sci., 99, 366-394 (2007).

5. M. M. Peden-Adams, J. M. Keller, J. G. EuDaly, J. Berger, G. S. Gilkeson and D. E. Keil, Toxicol. Sci., 104, 144-154 (2008).

6. Y. H. Kim and E. S. Cho, Korean J. Vet. Res., 48(3), 347-355(2008).

7. J. W. Martin, D. C. G. Muir, C. A. Moody, D. A. Ellis, W. C. Kwan, K. R. Solomon and S. A. Mabury, Anal. Chem., 74, 584-590 (2002).

8. J. P. Giesy and K. Kannan, Environ. Sci. Technol., 35, 1339-1342 (2001).

9. N. L. Stock, F. K. Lau, D. A. Ellis, J. W. Martin, D. C. G. Muir and S. A. Mabury, Environ. Sci. Technol., 39, 991-996 (2004).
10. M. Y. Shin and J. K. Im, J. Env. Health. Sci., 35(4), 334-342 (2009).

11. M. Murakami, E. Imamura, H. Shinohara, K. Kiri, Y. Muramatsu, A. Harada and H. Takada, Environ. Sci. Technol., 42, 6566-6572 (2008).

12. M. J. Dinglasan, Y. Ye, E. A. Edwards and S. A. Mabury, Environ. Sci. Technol., 38, 2857-2864 (2004).

13. Risk \& Policy Analysis Limited (in association with BRE Environment), 'Proposal for Regulations on PFOS-Related Substances' prepared for Department for Environment, Food and Rural Affairs, Chemicals and GM Policy Division, UK, 4-5, 2004.

14. K. Prevedouros, I. T. Cousins, R. Buck and S. H. Korzeniowski, Environ. Sci. Tech., 40(1), 32-44 (2006).

15. M. J. Strynar, A. B. Lindstrom, S. F. Nakayama, P. P. Egeghy and L. J. Helfant, Chemosphere, 86, 252-257 (2012).

16. P. Labadie and M. Chevreuil, Environ. Pollt., 159, 391397 (2011).

17. L. Yang, L. Zhu and L. Zhengtao, Chemosphere, 83, 806-814 (2011).

18. J. E. Naile, J. S. Khim, T. Wang, C. Chen, W. Luo, B. O. Kwon, J. Park, C. H. Koh, P. D. Jones, Y. Lu and J. P. Giesy, Environ. Poll., 158, 1237-1244 (2010).

19. C. L. Tseng, L. L. Liu, C. M. Chen and W. H. Ding, J. Chromatography A, 1105, 119-126 (2006).

20. K. J. Hansen, H. O. Johnson, F. S. Eldridge, J. L. Butenhoff and L. A. Dick, Environ. Sci. Technol., 36, 16811685 (2002).

21. M. Clara, O. Gans, S. Weiss, D. Sanz-Escribano, S. Scharf and C. Scheffknecht, Water Res., 43, 4760-4768 (2009). 